\title{
The use of bacteriophages to differentiate serologically cross-reactive isolates of Klebsiella pneumoniae
}

\author{
P. PIERONI*, R. P. RENNIE†, B. ZIOLA* and H. G. DENEER* $\ddagger$ \\ * Department of Microbiology, University of Saskatchewan, Saskatoon, Saskatchewan S7N OWO, †Department of \\ Medical Microbiology and Infectious Diseases, University of Alberta, Edmonton, Alberta T6G $2 B 7$ and $\ddagger D i v i s i o n$ of \\ Clinical Microbiology, Royal University Hospital, Saskatoon, Saskatchewan S7N OXO, Canada
}

\begin{abstract}
Summary. In serological typing of Klebsiella pneumoniae strains from human, equine and environmental sources, the capsular identity of many isolates could not be determined because of serological cross-reactivity. A panel of 91 bacteriophages able to lyse each of the 77 capsular serotypes of $K$. pneumoniae was isolated and tested for the ability to distinguish between strains in a collection of 17 clinical isolates of $K$. pneumoniae which exhibited crossreactivity with two or more capsular type sera. Most isolates could be assigned a capsular type by performing a simple streak test with bacteriophage, although some required the application of an efficiency of plating analysis to discern capsular type. Bacteriophage typing was found to be an effective, inexpensive and clinically practical adjunct to serotyping in distinguishing serologically cross-reactive $K$. pneumoniae isolates, irrespective of their origin.
\end{abstract}

\section{Introduction}

Klebsiella pneumoniae is an opportunist pathogen that is a major cause of nosocomial infections. ${ }^{1-4}$ In many hospitals, Klebsiella spp. are second only to Escherichia coli as the major cause of gram-negative bacteraemia. $^{5,6}$ As an increasing proportion of $K$. pneumoniae isolates are resistant to commonly used antibiotics, ${ }^{1,7}$ it is not surprising that reported mortality rates for $K$. pneumoniae bacteraemia and pneumonia range from c. $25-50 \%{ }^{2.8}$ Klebsiella spp. are also important in veterinary medicine, as a cause of equine metritis and bovine mastitis. ${ }^{9,10}$ Consequently, in both human and veterinary medicine, it is important to monitor and control the presence of $K$. pneumoniae.

Klebsiella spp. have been typed by various techniques, including bacteriocin typing, ${ }^{11}$ biotyping, ${ }^{12}$ serotyping, ${ }^{13,14}$ bacteriophage typing, ${ }^{15-17}$ antibioticsusceptibility testing, ${ }^{18}$ protein profiling, ${ }^{19}$ multilocus enzyme analysis, ${ }^{8,20}$ and several molecular techniques. ${ }^{8,18,21,22}$ Each typing method has drawbacks and recent reviews have detailed their limitations. ${ }^{23-25}$ Because of the limitations of employing a single approach to typing, some investigators have used two or more typing methods for improved discrimination between isolates. ${ }^{18,26-28}$

Although the current trend is toward the use of

Received 18 April 1994; revised version accepted 16 June 1994

$\ddagger$ Correspondence should be sent to Dr H. G. Deneer, Department

of Microbiology, University of Saskatchewan, Saskatoon,

Saskatchewan, Canada S7N OWO. molecular typing techniques, serological and bacteriophage typing methods are attractive to diagnostic laboratories because they are simple and can be easily and rapidly applied to many isolates. ${ }^{16,29}$ Initially, we monitored $K$. pneumoniae outbreaks by serotyping. However, clinical isolates exhibiting serological crossreactivity between two or more capsular serotypes were found regularly. As Przondo-Hessek, ${ }^{17}$ Sutherland, ${ }^{30}$ and Rieger-Hug and Stirm ${ }^{31}$ have shown that it is possible to obtain bacteriophages specific to a particular capsular serotype, or groups of serotypes, of Klebsiella spp., bacteriophage typing was evaluated as a supplement to serotyping to differentiate crossreacting Klebsiella serotypes. It was reasoned that bacteriophage typing would be an inexpensive, easy to perform method for differentiating $K$. pneumoniae isolates and would obviate the need for more complicated molecular typing methods. This study is the first report of the use of bacteriophages to differentiate between serologically cross-reacting capsular types of $K$. pneumoniae obtained from various sources.

\section{Materials and methods}

\section{Klebsiella strains}

Reference strains of Klebsiella serotypes K1-72, K74 and K79-82 were obtained from Dr I. Ørskov, Collaborative Centre for Reference Research on Escherichia and Klebsiella, World Health Organization, Statens Seruminstitut, Copenhagen, Den- 
mark. ${ }^{32}$ Isolates of $K$. pneumoniae from human, veterinary and environmental sources were obtained over a 5-year period through submission to one of us (R.P.R.) for epidemiological serotyping. Isolates 71406 and 41-50538 were from human infections; isolates Fibar-2, Fibar-3, UG-971, UG-972, UG50888, CR-14974, CR-15831, CR-15857, CR-16131, CR-16452, CR-16661, CR-16941 and CR-17124 were from equine infections; CR-15881 was isolated from the floor of an equine breeding area; and isolate SCW5489 was obtained from city water. Isolates were identified as $K$. pneumoniae by the AMS-Vitek Identification System (Hazelwood, MO, USA).

\section{Capsular serotyping}

The capsular serotypes of clinical isolates were determined by the Quellung test as described previously. ${ }^{33} \mathrm{~A}$ light suspension of bacteria was prepared by touching several individual colonies from MacConkey agar plates and mixing in $1 \mathrm{ml}$ of formalin $1 \%$ in saline. A $10-\mu 1$ sample of this suspension was mixed with an equal volume of pooled $K$. pneumoniae antiserum, placed on a slide and viewed by phase contrast microscopy. Each pool of antisera comprised three to six individual sera ${ }^{34}$ When a positive Quellung reaction was obtained, individual capsular antisera were used to determine which capsular type had produced the positive reaction. Capsular cross-reactivity between isolates was also screened in this manner.

Capsular type antisera were prepared by immunising New Zealand White rabbits with each strain from the Danish set of 77 Klebsiella serotypes as described by Edwards and Ewing. ${ }^{34}$ All rabbits were pre-screened to ensure that they were pasteurella-free and to ascertain any background titre to klebsiella capsular antigens. Antibody end-point titres were determined by a Quellung reaction with two-fold dilutions of serum in $50 \mathrm{mM}$ Tris- $\mathrm{HCl}, \mathrm{pH} \mathrm{7.5}$, containing $100 \mathrm{mM} \mathrm{NaCl}$ and $8 \mathrm{mM} \mathrm{Mg}_{2} \mathrm{SO}_{4}$ (SM buffer). The highest serum dilution that gave a positive Quellung reaction was taken as the titre. The titre of serologically cross-reacting sera was determined similarly. All antisera were stored at $-70^{\circ} \mathrm{C}$ after adding sodium azide $0 \cdot 1 \% \mathrm{w} / \mathrm{v}$.

\section{Bacteriophage isolation}

Bacteriophages able to replicate in each of the 77 Klebsiella serotypes were isolated from raw sewage. Fifty $\mathrm{ml}$ of double strength Luria Broth (LB) were mixed with $50 \mathrm{ml}$ of sewage and $10 \mathrm{ml}$ of an overnight culture of each of the serotypes. After incubation for $18 \mathrm{~h}$ at $37^{\circ} \mathrm{C}$ with shaking $(100 \mathrm{rpm})$ in a water bath, chloroform $1 \% \mathrm{v} / \mathrm{v}$ was added. The sample was then incubated at room temperature for $30 \mathrm{~min}$ to lyse the bacteria. After centrifugation at $10000 \mathrm{~g}$ for $10 \mathrm{~min}$ to remove cellular debris, the supernate was removed and filtered through a $0 \cdot 45-\mu \mathrm{m}$ Nalgene filter, Type $\mathrm{S}$ (Nalgene Company, Rochester, NY, USA). To con- firm the presence of bacteriophage in the filtrate, a drop was streaked on to a plate containing an agar overlay of the Klebsiella serotype used to seed the raw sewage. The plate was examined for lytic activity after incubation at $37^{\circ} \mathrm{C}$. All bacteriophages were plaquepurified five times, and the final cell lysate was assayed to titre and stored over chloroform $1 \% \mathrm{v} / \mathrm{v}$ at $4^{\circ} \mathrm{C}$. Most of the bacteriophage suspensions had a titre in the range $10^{8}-10^{10}$ plaque forming units $/ \mathrm{ml}$. In this report, each bacteriophage is identified by the capsular serotype number of its initial host bacterium. Two or more distinct bacteriophages isolated from the same Klebsiella serotype (based upon plaque morphology) are designated by lower case letters.

\section{Determination of bacteriophage cross-infectivity}

The routine test dilution (RTD) was taken to be the dilution of bacteriophage that just failed to give confluent lysis of the Klebsiella host strain on which it was first isolated. RTDs are used routinely in phage typing because phages have different burst and particle sizes, both of which can influence the concentration at which a particular phage will give semi-confluent lysis of its bacterial host. For phage typing, a $0 \cdot 45-\mathrm{ml}$ sample of an overnight culture of the Klebsiella isolate to be typed was diluted in $5 \mathrm{ml}$ of LB-soft agar $(0.75 \%$ agar), poured over an LB agar plate $(9 \mathrm{~cm}$ diameter), and allowed to dry for $30 \mathrm{~min}$. A $25-\mu \mathrm{l}$ sample of each bacteriophage suspension at its RTD was placed as a drop on to the agar overlay of the test organism and dragged as a streak across the overlay with a small strip $(8 \times 60 \mathrm{~mm})$ of sterile Whatman No. 1 filter paper. This filter streaking technique resulted in a concentration gradient of phage across the plate and eliminated the possibility of obtaining non-infectious lysis of the test bacteria as can occur with too high a concentration of phage. After overnight incubation at $37^{\circ} \mathrm{C}$, the plate was scored for the presence of lytic activity as indicated by the presence of 20 or more plaques, or a clear or turbid lytic area, along the streak line. Cultures to be typed were each tested a minimum of three times with the appropriate bacteriophages. Identical results were obtained each time.

Efficiency of plating (EOP) assays were also performed to quantitate the ability of bacteriophages to cross-infect other Klebsiella serotypes. The EOP value is a ratio indicating how well a bacteriophage plates on a heterologous Klebsiella serotype compared to the Klebsiella serotype first used to isolate the bacteriophage. ${ }^{35}$ An EOP of $<100 \%$ indicates that some form of host restriction is occurring. Samples of serial 10fold dilutions (in SM buffer) of the respective phage suspensions were incubated for $15 \mathrm{~min}$ with the isolating host and with a heterologous host. Each mixture was diluted into $5 \mathrm{ml}$ of LB-soft agar and layered on to an LB agar plate. The plates were incubated overnight at $37^{\circ} \mathrm{C}$ and scored for the presence of plaques. In this laboratory, EOP values for the various bacteriophages have remained stable for $>3$ years. 


\section{Results}

\section{Capsular serotyping of $K$. pneumoniae}

Most of the rabbit antisera generated against the 77 Klebsiella capsular serotypes had titres $\geqslant 16$ and a few had titres as high as 128 (partial listing in table I). However, for several capsular types, the antiserum titre could not be raised above 8 and, in two cases, the titre could not be raised above 4 . The majority of the 77 rabbit klebsiella capsular antisera reacted with more than one capsular serotype (partial listing in table I). Initial attempts were made to adsorb the antisera with cross-reacting capsular serotypes, but in several cases, this eliminated the Quellung titre for the capsular serotype used for immunisation. Because the titre against a cross-reacting capsular type was frequently $<25 \%$ of the titre against the capsular type used for immunisation, attempts were made to reduce the interference posed by cross-reactivity by diluting the antisera when performing Quellung reactions. Because of the subjectivity inherent in interpreting the Quellung reaction, this approach to discriminating serotypes was difficult to reproduce and could not be done at all when the titres to the immunising and crossreacting capsular types were very similar.

\section{Isolation of klebsiella capsular type-specific bacteriophages}

A total of 91 bacteriophages was isolated which lysed the 77 Klebsiella capsular serotypes. For several of the capsular types, including K22, K46 and K64,

Table I. Serologically cross-reactive strains of Klebsiella*

\begin{tabular}{|c|c|}
\hline $\begin{array}{l}\text { Capsular type } \\
\text { (Quelling titre) }\end{array}$ & $\begin{array}{l}\text { Cross-reacting capsular type } \\
\text { (Quelling titre) }\end{array}$ \\
\hline K2 (16) & K13 (2) \\
\hline K7 (16) & $\mathrm{K} 10(8) ; \mathrm{K} 61(2)$ \\
\hline K8 (8) & $\mathrm{K} 25(2)$ \\
\hline K10 (64) & K7 (2); K61 (32) \\
\hline K11 (64) & K21 (2) \\
\hline $\mathrm{K} 12(16)$ & $\mathrm{K} 29(4) ; \mathrm{K} 42(8)$ \\
\hline K13 (32) & K30 (8) \\
\hline K14 (16) & K64 (16) \\
\hline K18 (32) & K44 (8) \\
\hline K21 (64) & $\mathrm{K} 11(16)$ \\
\hline K22 (64) & K37 (32) \\
\hline K24 (32) & K43 (4) \\
\hline K25 (8) & K8 (2) \\
\hline $\mathrm{K} 27(32)$ & K46 (16) \\
\hline K29(16) & $\mathrm{K} 12(2) ; \mathrm{K} 42(2)$ \\
\hline K30 (16) & K13 (4) \\
\hline K37 (64) & K22 (32) \\
\hline K42 (32) & K29 (2) \\
\hline K43 (4) & K24 (4) \\
\hline K44 (32) & K18 (8) \\
\hline K46 (64) & K27 (16) \\
\hline K61 (8) & $\mathrm{K} 7(2) ; \mathrm{K} 10(4)$ \\
\hline K64 (16) & K14 (2) \\
\hline
\end{tabular}

* The serological cross-reactivities shown relate to the crossreactive serotypes found for the 17 Klebsiella isolates listed in table III.
Table II. Efficiency of plating (EOP) of bacteriophages on their natural and heterologous cross-reacting Klebsiella serotype hosts

\begin{tabular}{|c|c|c|}
\hline $\begin{array}{c}\text { Host } \\
\text { capsular type }\end{array}$ & $\begin{array}{l}\text { Bacteriophage } \\
\text { plated }\end{array}$ & EOP $(\%)$ \\
\hline \multirow[t]{3}{*}{$\mathrm{K} 2$} & 2 & 100 \\
\hline & 13 & 0 \\
\hline & 30 & 0 \\
\hline \multirow[t]{3}{*}{ K7 } & 7 & 100 \\
\hline & 10 & $7 \cdot 3$ \\
\hline & 61 & 0 \\
\hline \multirow{2}{*}{$\mathrm{K} 8$} & 8 & 100 \\
\hline & 25 & 0 \\
\hline \multirow[t]{3}{*}{$\mathrm{K} 10$} & 10 & 100 \\
\hline & 7 & 0 \\
\hline & 61 & 0 \\
\hline \multirow[t]{2}{*}{ K11 } & 11 & 100 \\
\hline & 21 & 0 \\
\hline \multirow{3}{*}{$\mathrm{K} 12$} & 12 & 100 \\
\hline & 29 & $2.5 \times 10^{-4}$ \\
\hline & 42 & 0 \\
\hline \multirow{3}{*}{$\mathrm{K} 13$} & 13 & 100 \\
\hline & 2 & $1.4 \times 10^{-4}$ \\
\hline & 30 & 0 \\
\hline \multirow{3}{*}{ K14 } & 14 & 100 \\
\hline & $64 a$ & $2.0 \times 10^{-2}$ \\
\hline & $64 \mathrm{~b}$ & 0 \\
\hline \multirow{2}{*}{ K 18} & 18 & 100 \\
\hline & 44 & 0 \\
\hline \multirow{2}{*}{ K21 } & 21 & 100 \\
\hline & 11 & 85 \\
\hline \multirow[t]{3}{*}{$\mathrm{K} 22$} & $22 a$ & 100 \\
\hline & $22 \mathrm{~b}$ & 100 \\
\hline & 37 & 0 \\
\hline \multirow{2}{*}{ K24 } & 24 & 100 \\
\hline & 43 & 0 \\
\hline \multirow[t]{2}{*}{$\mathrm{K} 25$} & 25 & 100 \\
\hline & 8 & 0 \\
\hline \multirow[t]{3}{*}{ K27 } & 27 & 100 \\
\hline & $46 a$ & 100 \\
\hline & $46 \mathrm{~b}$ & 0 \\
\hline \multirow{3}{*}{ K 29} & 29 & 100 \\
\hline & 12 & 13 \\
\hline & 42 & 0 \\
\hline \multirow[t]{3}{*}{$\mathrm{K} 30$} & 30 & 100 \\
\hline & 2 & 0 \\
\hline & 13 & 0 \\
\hline \multirow[t]{3}{*}{ K37 } & 37 & 100 \\
\hline & $22 \mathrm{a}$ & 1.4 \\
\hline & $22 \mathrm{~b}$ & 56 \\
\hline K42 & 42 & 100 \\
\hline & 12 & 0 \\
\hline & 29 & $7.2 \times 10^{-6}$ \\
\hline K43 & 43 & 100 \\
\hline & 24 & 0 \\
\hline K44 & 44 & 100 \\
\hline & 18 & 0 \\
\hline K46 & $46 a$ & 100 \\
\hline & $46 \mathrm{~b}$ & 100 \\
\hline & 27 & 0 \\
\hline K61 & 61 & 100 \\
\hline & 7 & 0 \\
\hline & 10 & $2.0 \times 10^{-3}$ \\
\hline K64 & $64 a$ & 100 \\
\hline & $64 \mathrm{~b}$ & 100 \\
\hline & 14 & $4.0 \times 10^{-2}$ \\
\hline
\end{tabular}

more than one bacteriophage was isolated. An EOP analysis was used to determine how effectively each bacteriophage was able to replicate in a cross-reacting heterologous capsular serotype compared to the Klebsiella capsular serotype used for isolation. Because 
Table III. Bacteriophage differentiation of $K$. pneumoniae isolates showing serological cross-reactivity

\begin{tabular}{|c|c|c|c|c|}
\hline $\begin{array}{l}\text { Isolate } \\
\text { no. }\end{array}$ & $\begin{array}{l}\text { Cross-reactive } \\
\text { serotypes* }\end{array}$ & $\begin{array}{l}\text { Bacteriophage } \\
\text { streaked } \dagger\end{array}$ & $\begin{array}{l}\text { Lytic } \\
\text { activity }\end{array}$ & $\begin{array}{l}\text { Phage- } \\
\text { determined } \\
\text { type } \ddagger\end{array}$ \\
\hline $7-1406$ & $\mathrm{~K} 22 / 37$ & $\begin{array}{l}22 a \\
22 b \\
37\end{array}$ & $\begin{array}{l}+ \\
- \\
-\end{array}$ & $\mathrm{K} 22$ \\
\hline $41-50538$ & K22/37 & $\begin{array}{l}22 \mathrm{a} \\
22 \mathrm{~b} \\
37\end{array}$ & $\begin{array}{l}- \\
- \\
+\end{array}$ & K37 \\
\hline Fibar-2 & K $18 / 44$ & $\begin{array}{l}18 \\
44\end{array}$ & - & K44 \\
\hline Fibar-3 & K $27 / 46$ & $\begin{array}{l}27 \\
46 a \\
46 b\end{array}$ & $\begin{array}{l}+ \\
- \\
-\end{array}$ & $\mathrm{K} 27$ \\
\hline SCW-5489 & K $14 / 64$ & $\begin{array}{l}14 \\
64 \mathrm{a} \\
64 \mathrm{~b}\end{array}$ & $\begin{array}{l}- \\
+ \\
-\end{array}$ & K64 \\
\hline UG-971 & $\mathrm{K} 12 / 29 / 42$ & $\begin{array}{l}12 \\
29 \\
42\end{array}$ & $\begin{array}{l}+ \\
+ \\
-\end{array}$ & $\mathrm{K} 29 \S$ \\
\hline UG-972 & $\mathrm{K} 24 / 43$ & $\begin{array}{l}24 \\
43\end{array}$ & - & K43 \\
\hline UG-50888 & $\mathrm{K} 8 / 25$ & $\begin{array}{r}8 \\
25\end{array}$ & $\bar{t}$ & $\mathrm{~K} 25$ \\
\hline CR-14974 & $\mathrm{K} 22 / 37$ & $\begin{array}{l}22 \mathrm{a} \\
22 \mathrm{~b} \\
37\end{array}$ & $\begin{array}{l}- \\
+ \\
-\end{array}$ & $\mathrm{K} 22$ \\
\hline CR-15831 & $\mathrm{K} 7 / 10 / 61$ & $\begin{array}{r}7 \\
10 \\
61\end{array}$ & $\begin{array}{l}- \\
+ \\
+\end{array}$ & K61 \\
\hline CR-15857 & $\mathrm{K} 7 / 10 / 61$ & $\begin{array}{r}7 \\
10 \\
61\end{array}$ & $\begin{array}{l}+ \\
+ \\
-\end{array}$ & K7 \\
\hline CR-15881 & $\mathrm{K} 11 / 21$ & $\begin{array}{l}11 \\
21\end{array}$ & $\begin{array}{l}- \\
+\end{array}$ & $\mathrm{K} 21$ \\
\hline CR-16131 & $\mathrm{K} 14 / 64$ & $\begin{array}{l}14 \\
64 a \\
64 b\end{array}$ & $\begin{array}{l}+ \\
+ \\
+\end{array}$ & K64 \\
\hline CR-16452 & $\mathrm{K} 7 / 10 / 61$ & $\begin{array}{c}7 \\
10 \\
61\end{array}$ & $\begin{array}{l}+ \\
+ \\
-\end{array}$ & $\mathrm{K} 7$ \\
\hline CR-16661 & $\mathrm{K} 2 / 13 / 30$ & $\begin{array}{r}2 \\
13 \\
30\end{array}$ & $\begin{array}{l}- \\
- \\
+\end{array}$ & $\mathrm{K} 30$ \\
\hline CR-16941 & K $14 / 64$ & $\begin{array}{l}14 \\
64 \mathrm{a} \\
64 \mathrm{~b}\end{array}$ & $\begin{array}{l}+ \\
+ \\
-\end{array}$ & $\mathrm{K} 14 \S$ \\
\hline CR-17124 & $\mathrm{K} 2 / 13 / 30$ & $\begin{array}{r}2 \\
13 \\
30\end{array}$ & $\begin{array}{l}+ \\
+ \\
-\end{array}$ & $\mathrm{K} 13$ \\
\hline
\end{tabular}

* Serotype of the clinical isolate determined by the Quellung reaction.

$\dagger$ Bacteriophages were used at a concentration of 1 RTD, except as follows: bacteriophages $37,22 \mathrm{a}, 22 \mathrm{~b}$ were used at 16 RTD; bacteriophage 11 was used at 1024 RTD; and bacteriophage 21 was used at 512 RTD.

$\ddagger$ The type assigned to the isolate on the basis of the lytic pattern obtained with the indicated bacteriophage.

$\S$ Phage typing assignment required a complete EOP analysis (see table IV).

the intent was to validate the use of bacteriophages to distinguish between serologically cross-reactive Klebsiella isolates, the EOP values were determined only for those combinations of phage and host serotypes relevant to the clinical isolates examined later (see below). The EOP results (table II) revealed that while most bacteriophages were specific for the host capsular type on which they were isolated initially, some, such as $11,22 \mathrm{~b}$ and $46 \mathrm{a}$, replicated almost equally well on other Klebsiella capsular types as they did on the capsular types in which they were first isolated.

\section{Bacteriophage typing of serologically cross-reactive $K$. pneumoniae}

Over a 5 -year period, 17 isolates of $K$. pneumoniae which were serologically untypable because of crossreactivity with two or more capsular antisera were collected from various sources. Bacteriophages showing specificity for each of the cross-reacting capsular serotypes (table II) were tested for their ability to produce plaques on these isolates. As shown in table III, 15 of 17 isolates could be directly assigned to a 
Table IV. Differentiation of cross-reactive serotypes of $K$. pneumoniae by bacteriophage EOP analysis

\begin{tabular}{lccc}
\hline $\begin{array}{l}\text { lsolate } \\
\text { no. }\end{array}$ & $\begin{array}{c}\text { Cross-reactive } \\
\text { serotypes }\end{array}$ & $\begin{array}{c}\text { Bacteriophage } \\
\text { plated }\end{array}$ & $\begin{array}{c}\text { EOP } \\
(\%)^{*}\end{array}$ \\
\hline UG-971 & K12/29/42 & 12 & 5 \\
& & 29 & 42 \\
CR-16941 & K14/64 & 42 & 0 \\
& & 14 & $2 \cdot 0 \times 10^{-2}$ \\
& & $64 \mathrm{a}$ & $1 \cdot 8 \times 10^{-3}$ \\
& & $64 \mathrm{~b}$ & 0
\end{tabular}

* Plating of the indicated bacteriophage on the Klebsiella capsular type used for the initial isolation of the phage was taken as $100 \%$.

particular capsular type from their sensitivity to typespecific bacteriophage. For example, Fibar-2, UG-972 and UG-50888 were found to be capsular types K44, $\mathrm{K} 43$ and $\mathrm{K} 25$, respectively, because the bacteriophages isolated originally in these capsular serotypes were able to replicate on the three clinical isolates. These capsular assignments are validated by the EOP values in table II which show that, within this particular group of serotypes, bacteriophages 44,43 , and 25 show complete specificity.

For six of these 15 isolates (CR-15831, CR-15857, CR-16131, CR-16452, CR-16661 and CR-17124), it was necessary to use additional information provided by the EOP values from table II before a capsular identity could be determined. For example, the clinical isolate CR-15831 demonstrated K7/10/61 capsular cross-reactivity by serotyping and was lysed by bacteriophages 10 and 61 , but not by bacteriophage 7 (table III). By comparing the EOP values of bacteriophages 7, 10 and 61 on Klebsiella capsular types K7, $\mathrm{K} 10$ and $\mathrm{K} 61$, and by comparing this to the ability of these three bacteriophages to grow on isolate CR15831 , it was determined that the isolate had capsular type K61. Similar reasoning applied to the other five isolates.

For the last two Klebsiella isolates included in this study, a simple streak test or a streak test combined with an EOP analysis as above, did not allow us to discern directly the capsular type. Isolate UG-971 was either K12 or K29 and isolate CR-16941 was either K14 or a K64 variant (table III). Therefore, the EOP for bacteriophages 12,29 and 42 on isolate UG-971, and bacteriophages $14,64 \mathrm{a}$ and $64 \mathrm{~b}$ on isolate CR16941 were determined. Results presented in table IV indicate that clinical isolates UG-971 and CR-16941 were of capsular types K29 and K14, respectively.

Of interest was the observation that phage typing of isolates 7-1406, 41-50538, Fibar-3, SCW-5489, CR14974 and CR-15881 (table III) suggested that they were capsular type variants of $K$. pneumoniae serotypes K22, K37, K27, K64, K22 and K21, respectively. For example, isolate 7-1406 was a K22 capsular type variant because bacteriophage $22 \mathrm{a}$ was able to plaque on this isolate, while bacteriophage $22 \mathrm{~b}$ was not, even though both bacteriophages show identical EOP values for growth in the original $K$. pneumoniae $\mathrm{K} 22$ host strain (table II). Similarly, isolate 41-50538 was typed as a capsular K 37 variant because it was lysed by bacteriophage 37 but not bacteriophages 22a and 22b, despite the fact that these latter two phages could grow with a reduced EOP in the original Klebsiella capsular type K37 (table II).

Finally, it should be noted that bacteriophages were obtained which were also able to discriminate Klebsiella capsular types 1 and 6,2 and 69, 3 and 68,33 and 35 , and 70 and 72 . This was determined by using the Danish set of Klebsiella serotypes as host strains (data not shown). Clinical isolates have not yet been encountered which possess these capsular serotypes. Nevertheless, this bacteriophage panel allows the typing of a wider range of serologically cross-reacting Klebsiella capsular types than is shown in table III.

\section{Discussion}

Serotyping continues to be used in the epidemiological surveillance of $K$. pneumoniae outbreaks, ${ }^{16,29}$ although it tends to be restricted to reference centres or large hospitals that can underwrite the cost of generating antisera to the 77 Klebsiella capsular types. However, in the serotyping of $K$. pneumoniae, two main drawbacks are encountered. The first is the weak immune response induced by Klebsiella capsular polysaccharide which results in sera of low titre. ${ }^{36,37}$ The second is the occurrence of serological cross-reactivity between various capsular types (table I), because $>$ $50 \%$ of capsular antisera show cross-reactivity with one or more capsular types. ${ }^{14,36,37}$ This serological cross-reactivity is likely to be due to the limited number of moieties comprising the capsular material ${ }^{31}$ and to the presence of shared lipopolysaccharide groups which may intercalate between the capsule and be accessible at the surface. ${ }^{38}$ Therefore, it is not surprising that in attempting to obtain monospecific capsular antiserum by adsorbing with the crossreacting capsular type, a significant reduction or total elimination of antibodies reacting with the immunising capsular type was observed. Moreover, other workers ${ }^{36,37}$ and ourselves have found that antisera to the same capsular type can display variable capsular cross-reactivity.

Against this background of problems inherent in serotyping, the aim of this study was to determine if bacteriophages isolated by their ability to lyse specific Klebsiella capsular types could differentiate between isolates showing serological cross-reactivity. Bacteriophages able to replicate in each of the 77 Klebsiella capsular types were readily isolated from sewage. Evidence that these bacteriophages could be used to discriminate serologically cross-reactive $K$. pneumoniae capsular types came from EOP values for growth of the bacteriophages in those capsular type strains of Klebsiella that presented cross-reactivity problems. The EOP data showed that within a group of serotypes, bacteriophages could be identified which 
were completely specific for one of the serotypes within that group. It must be noted that because a large-scale EOP analysis of all possible bacteriophage-host serotype combinations has not been done, it is possible that many of these phages will infect other serotypes of Klebsiella. This has been reported previously by Gaston et al. ${ }^{16}$ who identified groups of serotypes lysed by particular phages but not phages which were completely type-specific. Importantly, however, EOP analysis revealed that within a limited group of Klebsiella serotypes, specifically those which show serological cross-reactivity, it is possible to obtain phages that discriminate within that group. To demonstrate the practicality of this approach, a panel of bacteriophages was used in a simple streak test to assign directly a capsular type to 15 of 17 clinical isolates of $K$. pneumoniae which had previously been untypable due to serological cross-reactivity. For most of the isolates, a bacteriophage RTD of 1 was sufficient, although for isolates CR14974 and CR15881, higher RTDs were required. The reason for this is not known, although it is common to use higher bacteriophage RTD values than used here to type organisms. $^{27,39}$

For isolates UG-971 and CR-16941, the capsular type could not be discerned directly by a simple streak test. However, by using an EOP analysis for bacteriophage replication in these two isolates (table IV), a capsular type was assigned in both cases. Earlier, Przondo-Hessek $^{17}$ showed that a bacteriophage able to infect several different Klebsiella capsular types lost this cross-infectivity if passaged at least 10 times on the capsular type used for initial isolation. Should this procedure be generally applicable for generation of capsular-specific bacteriophages, applying it to bacteriophages 12 and 29, for example, might render these two phages specific for capsular types K12 and K29. Such phages could then be used in a simple streak test and obviate the need to perform an EOP analysis to determine a capsular type.

We do not know whether the Klebsiella bacteriophages require a specific capsular type for infectivity or whether other factors such as a cellular bacteriophage receptor are also involved. Nonetheless, the data on the typing of serologically cross-reactive isolates suggests that at least some of the bacteriophages do not simply recognise the capsule of their Klebsiella host. This is illustrated by the disparate typing patterns of bacteriophages $22 \mathrm{a}$ and $22 \mathrm{~b}$ with $K$. pneumoniae isolates 7-1406 and CR14974, which showed serological cross-reactivity but were clinically distinct (table III). If the capsule was the only factor involved in infectivity, bacteriophages $22 \mathrm{a}$ and $22 \mathrm{~b}$ should each have infected both isolates, because both phages replicate equally well on Klebsiella capsular type K22. The inability of a bacteriophage to replicate in a particular host could be due to a number of factors, including changes in a bacteriophage receptor, ${ }^{40}$ host restriction mechanisms, or immunity resulting from lysogeny. ${ }^{41}$ Therefore, variability in bacteriophage susceptibility points to some degree of divergence among the bacteria themselves. As evidence of this, six isolates were encountered that were termed variants of their respective capsular type based upon the bacteriophage typing results. Presumably, typing with antisera lacks the sensitivity to detect and discriminate among such variants.

Other studies have used bacteriophage typing alone or in combination with other typing techniques to differentiate, classify, and monitor $K$. pneumoniae infections. ${ }^{15-18,26,27}$ Ayling-Smith and Pitt, ${ }^{23}$ for example, considered phage typing to be an excellent secondary typing method when used in conjunction with serotyping. This study has shown for the first time that bacteriophage typing readily differentiates between serologically cross-reacting $K$. pneumoniae capsular types irrespective of their human, animal or environmental origins. Although molecular typing techniques can be used in epidemiological investigations, these methods are costly, labour intensive, and lack standardised interpretive criteria, ${ }^{24,28}$ which so far has limited their use to reference centres or research laboratories. In contrast, bacteriophage typing is inexpensive and can be used in clinical laboratories without great technical expertise, as the streak assay and even EOP assays are straight-forward to perform and give easily interpreted results. Bacteriophage typing proved to be a simple and costeffective method which has the ability to distinguish serologically cross-reacting $K$. pneumoniae capsular types. As such, it should be of considerable benefit in epidemiological investigations.

We thank Dr I. Ørskov for providing the standard strains of 77 Klebsiella capsular serotypes and Linda Hellman for performing the Quellung reactions. P.P, was the recipient of a College of Medicine Graduate Scholarship, a University of Saskatchewan Graduate Student Scholarship and a Bursary from the Government of the Canadian Northwest Territories.

pneumoniae from ventilater condensate. $J$ Hosp Infect 1993; 23: 27-34.

4. Montgomerie JZ, John JF, Atkins I.M, Gilmore DS, Ashley MA. Increased frequency of large R-plasmids in Klebsiella pneumoniae colonizing patients with spinal cord injury. Diagn Microbiol Infect Dis 1993; 16: 25-29

5. Bryan CS, Reynolds KL. Brenner ER. Analysis of 1186 episodes of gram-negative bacteremia in non-university hospitals: the effects of antimicrobial therapy. Rer Infect Dis 1983:5: 629-638.

6. Bone RC. Gram-negative sepis: a dilemma of modern medicine. Clin Microbiol Ror 1993: 6: 57-68. 
7. Johnson AP, Weinbren MJ, Ayling-Smith B, Du Bois SK, Amyes SGB, George RC. Outbreak of infection in two UK hospitals caused by a strain of Klebsiella pneumoniae resistant to cefotaxime and ceftazidime. $J$ Hosp Infect 1992; 20: 97-103.

8. Bingen EH, Desjardins $\mathrm{P}$, Arlet G et al. Molecular epidemiology of plasmid spread among extended broad-spectrum $\beta$ lactamase-producing Klebsiella pneumoniae isolates in a pediatric hospital. J Clin Microbiol 1993; 31 : 179-184.

9. Braman SK, Eberhart RJ, Asbury MA, Hermann GJ. Capsular types of Klebsiella pneumoniae associated with bovine mastitis. J Am Vet Med Assoc 1973; 162: 109-111.

10. Platt H, Atherton JG, Ørskov I. Klebsiella and Enterobacter organisms isolated from horses. $J$ Hyg 1976; 77: 401-408.

11. Slopek S, Maresz-Babczyszyn A. A working scheme for typing Klebsiella bacilli by means of pneumocins. Arch Immunol Ther Exp 1967; 15: 525-529.

12. Kuhn I, Burman LG, Eriksson L, Mollby R. Subtyping of Klebsiella by biochemical fingerprinting: a simple system for epidemiological investigations. J Microbiol Methods $1990 ; 11: 177-185$.

13. Durlakowa I, Lachowicz Z, Slopek S. Serologic characterization of Klebsiella bacilli on the basis of properties of the capsular antigens. Arch Immunol Ther Exp 1967; 15: 497-504.

14. Palfreyman JM. Klebsiella serotyping by counter-current immunoelectrophoresis. J Hyg 1978; 81: 219-225.

15. Byczynska B, Przondo-Mordarska A, Kurlenda J. Phage typing of Klebsiella strains in epidemiological studies. Arch Immunol Ther Exp Warsz 1989; 37: 681-686.

16. Gaston MA, Ayling-Smith BA, Pitt TL. New bacteriophage typing scheme for subdivision of the frequent capsular serotypes of Klebsiella spp. J Clin Microbiol 1987; 25 : $1228-1232$.

17. Przondo-Hessek A. Bacteriophages of Klebsiella bacilli. Isolation, properties and use in typing. Arch Immunol Ther Exp 1966; 14: 413-435.

18. Hartstein AI, Morthland VH, Rourke JW, Sykes R, Rashad AL. Plasmid DNA analysis, biotyping, and antimicrobic susceptibility as subtyping tests for Klebsiella pneumoniae and Klebsiella oxytoca. Diagn Microbiol Infect Dis 1993; 16: $35-41$

19. Costas M, Holmes B, Sloss LL. Comparison of SDS-PAGE protein patterns with other typing methods for investigating the epidemiology of 'Klebsiella aerogenes'. Epidemiol Infect 1990; 104: 455-465.

20. Combe ML, Pons JL, Sesboue R, Martin JP. Electrophoretic transfer from polyacrylamide gel to nitrocellulose sheets, a new method to characterize multilocus enzyme genotypes of Klebsiella strains. Appl Environ Microbiol 1994; 60: 26-30.

21. Poh CL, Yap SC, Yeo M. Pulsed-field gel electrophoresis for differentiation of hospital isolates of Klebsiella pneumoniae. $J$ Hosp Infect 1993; 24 : 123-128.

22. Haertl R, Barten R, Bandlow G. Epidemiological fingerprinting of Klebsiella pneumoniae by small-fragment-restrictionendonuclease-analysis (SF-REA). Scand J Infect Dis 1991; 23: 737-743.

23. Ayling-Smith B, Pitt TL. State of the art in typing: Klebsiella spp. J Hosp Infect 1990; 16: 287-295.
24. Miller JM. Molecular technology for hospital epidemiology. Diagn Microbiol Infect Dis 1993; 16: 153-157.

25. Pfaller MA. Typing methods for epidemiologic investigations. In: Balows A, Hausler WJ, Herrmann KL et al. (eds) Manual of clinical microbiology, 5th edn. American Society for Microbiology, Washington, D.C. 1991: 171-182.

26. Podschun R, Heineken P, Ullmann U, Sonntag HG. Comparative investigations of Klebsiella species of clinical origin: plasmid patterns, biochemical reactions, antibiotic resistances and serotypes. Zentralbl Bakteriol Mikrobiol Hyg (A) 1986; 262: 335-345.

27. Rennie RP, Nord CE, Sjoberg L, Duncan IBR. Comparison of bacteriophage typing, serotyping, and biotyping as aids in epidemiological surveillance of Klebsiella infections. J Clin Microbiol 1978; 8: 638-642.

28. Persing DH. Diagnostic molecular microbiology. Current challenges and future directions. Diagn Microbiol Infect Dis 1993; 16: 159-163

29. Mori M, Ohta M, Agata $\mathrm{N}$ et al. Identification of species and capsular types of Klebsiella clinical isolates, with special reference to Klebsiella planticola. Microbiol Immunol 1989; 33: 887-895.

30. Sutherland IW. Highly specific bacteriophage-associated polysaccharide hydrolases for Klebsiella aerogenes type 8. $J$ Gen Microbiol 1976; 94: 211-216.

31. Rieger-Hug D, Stirm S. Comparative study of host capsule depolymerases associated with Klebsiella bacteriophages. Virology 1981; 113: 363-378.

32. Ørskov I, Fife-Asbury MA. New Klebsiella capsular antigen, $\mathrm{K} 82$, and the deletion of five of those previously assigned. Int J Syst Bacteriol 1977; 27 : 386-387.

33. Finegold SM, Martin WJ, Scott EG. Bailey and Scott's diagnostic microbiology, 5th edn. St Louis, Missouri, C. V. Mosby Co. 1978.

34. Edward PR, Ewing WH. Identification of Enterobacteriaceae, 3rd edn. Minneapolis, Minnesota, Burgess Publishing Co. 1972: 299.

35. Burns RO, Blazey DL. Genetic variation and gene transfer. In: Joklik WK, Willett HP, Amos DB (eds) Zinsser Microbiology, 18th edn. Norwalk, Connecticut, AppletonCentury-Crofts. 1984: 159-190.

36. Edmondson AS, Cooke EM. The production of antisera to the Klebsiella capsular antigens. J Appl Bacteriol 1979; 46: 579-584.

37. Henriksen SD. Studies on the Klebsiella group (Kauffmann) I. Sero-types of a collection of strains from human sources and from water. Acta Pathol Microbiol Scand 1954; 34: 249-258.

38. Tomás JM, Camprubi S, Merino S, Davey MR, Williams P. Surface exposure of $\mathrm{O} 1$ serotype expressing different $\mathrm{K}$ antigens. Infect Immun 1991; 59: 2006-2011.

39. Overturf GD, Talan DA, Singer K et al. Phage typing of Staphylococcus intermedius. J Clin Microbiol 1991; 29: 373-375.

40. Nordstrom K, Forsgren A. Effect of protein A on adsorption of bacteriophages to Staphylococcus aureus. J Virol 1974; 14 : 198-202.

41. Frost AJ, Bradshaw E. The role of lysogeny in the modification of phage typing patterns of Staphylococcus aureus from dairy cows. J Hyg 1980; 85: 301-307. 